\title{
Retroperitoneal Lymph Node
}

National Cancer Institute

\section{Source}

National Cancer Institute. Retroperitoneal Lymph Node. NCI Thesaurus. Code C98189.

A lymph node located in the retroperitoneal space. 